Last year, for example, as much as $87,000 \mathrm{kgm}$. of pure gold was extracted, and this exceeded the Canadian production. It also represented an increase of forty per cent over the amount obtained in 1932. More still is expected to be obtained in the present year.

\section{Grassland Research in Australia}

$I_{T}$ is not often that research workers are able to review the whole field of their particular investigation in their own country, but grassland agronomists in Australia are placed in this fortunate position by the appearance of Bulletin No. 14 of the Herbage Publication Series of the Institute of Agricultural Botany ("Grassland Research in Australia", Imperial Bureau of Plant Genetics, Aberystwyth, Great Britain, 3s., February 1934). The bulletin contains a comprehensive survey of Australian research work on pasture management and improvement, the genetics, pests and diseases of grass crops, poisonous plants, the introduction of new species and plant physiology as it relates to grasses. For each research centre, the names of the investigators, the scope of the work, experimental procedure and references to published results are given. Two original papers on "The Technique of Pasture Investigations" by J. Griffiths Davies and H. C. Trumble, and "Botanical Analysis of Irrigated Pasture" by E. S. Beruldsen and $\mathbf{A}$. Morgan are also included in the bulletin.

\section{Physics in National Planning}

IN an article on this subject which Prof. Karl T. Compton, of the Massachusetts Institute of Technology, contributes to the July issue of the Review of Scientific Instruments, he points out that physics has given birth to nearly all those ideas which have led to the understanding and use of the forces of Nature ; that almost every branch of industry has benefited from it, and that the pace at which it is developing at the present time assures us of its increasing power to help in the future. A nation which, by anti-educational policy or by inadequate provision for research, puts itself industrially at the mercy of more progressive nations, is courting economic distress and unemployment for the next generation. He considers that the United States Government, in spending only one half of one per cent of its annual budget on its scientific bureaux, is showing a lamentable lack of vision. He urges re-consideration of the place of science in national planning and policy, and better provision for it in the future.

\section{The U.S. National Research Council}

IN several issues of Science during 1933, articles by various authors have appeared surveying the organisation of, and suggestions for needed changes in, the United States National Research Council. These articles have now been issued in pamphlet form as a partial record of the accomplishments of the National Research Council ("A History of the National Research Council, 1919-1933". Washington, D.C. 1933. 50 cents). A survey of the organisation and activities of the Council is contributed by Dr.
Albert L. Barrows, its assistant secretary. The Council originated in an offer made by the National Academy of Sciences of its services to President Wilson in 1916, when it was seen that the United States would become involved in the War. The Council was finally established as a perpetual body on May 18, 1918. The organisation and activities of the following divisions are described by their respective chairmen: Physical Sciences, Prof. F. K. Richtmeyer; Engineering and Industrial Research, Prof. Dugald C. Jackson, Chemistry and Chemical Technology, Prof. Charles A. Kraus; Geology and Geography, Prof. W. H. Twenhofel ; Medical Sciences, Prof. Stanhope Bayne-Jones; Biology and Agriculture, Prof. Fernandus Payne; Anthropology and Psychology, Prof. A. T. Poffenberger. An account of the Research Information Service is contributed by its director, Dr. Clarence J. West, and the assistant secretary of the Council describes the various divisions of general relations (federal, foreign, States and educational). A list of publications is appended.

\section{History of Medicine Congress}

THIS year's Congress of the German Society of the History of Medicine will form part of the ninety-third Congress of the Society of German Men of Science and Physicians, which will be held at Hanover on September 18-19. The following subjects, among others, will be considered: bone finds in the Alamannic graves, by Prof. Georg Sticker ; racial ideas in India, by R. F. G. Moller; Velasquez and the doctrine of heredity by Prof. Haberling; a contribution to the study of medicinal plants, by Edith Heischkel; Cæsarean section by midwives, by Elsaluise Haberling; Novalis and Romanticism, by Prof. Paul Diepgen; Urso, the last doctor, philosopher and theologian at Salerno, by Dr. Rudolf Creotz; the medical faculty at the University of Tyrnau, by Prof. T. von Gyorgi; the correspondence of Drs. Zimmermann and Espenburg with Kotzebue, by Dr. W. Leibbrand; Kestren, the Frankfort municipal doctor, by Dr. Kallmorgen; national and politica1 tendencies in the congresses for natural science 1822-48, by Dr. Ludwig Englert, and Caspar Friedrich Wolff, by Dr. Julius Schuster. Further information can be obtained from Dr. W. Artelt, Universitatsstrasse $3 \mathrm{~b}$, Berlin, N.W.7.

\section{Sixth International Congress for Scientific Management}

Ax the Sixth International Congress for Scientific Management to be held in July of next year, arrangements have been made for the discussion of many papers giving accounts of management in relation to a variety of problems. These include business forecasting, budgetary control, the inculcation of best methods of management, production control and technique, standardisation, the distribution problems of manufacturers, wholesalers and retailers, selective education and training for high administrative positions. Many international and national problems would be affected by the greater use of scientific method. The management of 